\title{
Zagadnienia kulturalno-oświatowe na łamach pisma Związku Kombatantów Rzeczypospolitej Polskiej i Byłych Więźniów Politycznych
}

\section{Wprowadzenie}

W pracy historyka i historyka wychowania jednym ze źródeł, bywa że istotnym, jest prasa. Wykorzystanie zamieszczonych w kwartalnikach, periodykach czy tygodnikach artykułów zmusza badacza do dokonania właściwej ich interpretacji i selekcji oraz oceny porównawczej z dokumentami naukowymi. Klasyfikacja dokonana przez J. Topolskiego traktuje prasę jako źródło pośrednie (adresowane), w którym przedstawiona została interpretacja świata, dokonana przez jednego bądź kilku autorów źródła1. Wiadomości przedstawione w periodyku „Polsce Wierni” posłużyły mi jako materiał źródłowy do historii wychowania i pedagogiki w wybranych aspektach pracy z młodzieżą. Zaprezentowane fragmenty wymagały stosownej analizy i właściwej interpretacji. Korzystając z uprzejmości prezesa Koła Związku Kombatantów Rzeczypospolitej Polskiej i Byłych Więźniów Politycznych w Kłodzku, pana Zbigniewa Kani, mogłam zapoznać się z numerami pisma, opublikowanymi w latach 2003-2010.

Wybrałam artykuły, które zasługują na uwagę ze względu na prezentowane w nich wydarzenia z historii Polski, dotyczące postawy młodzieży w stosunku do ludzi starszych i roli szkoły w procesie nauczania i wychowania uczniów. Część poświęcona współpracy kombatantów z zagranicą ma na celu ukazanie wzajemnych

* Dr, Szkoła Wyższa im. Bogdana Jańskiego, 41-800 Zabrze, ul. Curie-Skłodowskiej 40.

1 J. Topolski, Jak się pisze $i$ rozumie historię. Tajemnice narracji historycznej, Warszawa 1996, s. 341. 
relacji osób, które - chociaż przeżyły trudy i cierpienia II wojny światowej oraz okres komunizmu - po wielu latach potrafią prowadzić dialog, starają się przekazać młodemu pokoleniu najlepsze wzorce.

\section{Związek Kombatantów Rzeczypospolitej Polskiej i Byłych Więźniów Politycznych}

Nazwę Związek Kombatantów Rzeczypospolitej Polskiej i Byłych Więźniów Politycznych (ZKRP i BWP) ${ }^{2}$ ustalono na Zjeździe Kombatantów w kwietniu 1990 r., kiedy dokonano reorganizacji Związku Bojowników o Wolność i Demokrację. ZKRP i BWP jest największą organizacją kombatancką w kraju, w której szeregach znajdują się członkowie zwyczajni oraz podopieczni. Pierwszą grupę stanowią weterani walk frontowych i uczestnicy organizacji podziemnego ruchu oporu, drugą zaś tworzą wdowy i wdowcy po kombatantach.

Na czele organizacji stoją Kongres, Zarząd Główny, Główna Komisja Rewizyjna i Główny Sąd Koleżeński. Zarządy Okręgowe i koła terenowe podlegają zwierzchnictwu Zarządu Głównego. Funkcjonowanie Związku reguluje Statut ZKRP i BWP z dnia 24 lipca $2003 \mathrm{r}$.

ZKRP i BWP ma charakter wielośrodowiskowy. Zrzesza Polaków, którzy w czasach II wojny światowej walczyli o wolność, suwerenność i niepodległość państwa. Jego członkowie należą do grona rodaków, walczących w szeregach Wojska Polskiego, sojuszniczych armii państw koalicji antyhitlerowskiej oraz podziemnych organizacji ruchu oporu. Są wśród nich także więźniowie obozów koncentracyjnych i łagrów stalinowskich.

Do zadań organizacji należą: kształtowanie aktywnej postawy członków, praca dla dobra kraju, tworzenie warunków do wzajemnej współpracy środowisk kombatanckich, umacnianie solidarności kombatantów w kraju i za granicą, reprezentowanie interesów związkowców wobec władz, a także otaczanie opieką i pomocą w kwestiach zdrowotno-socjalnych członków oraz podopiecznych. Działalność ZKRP i BWP ma na celu szerzenie i popularyzowanie w społeczeństwie wiedzy o dziejach walk o niepodległość, dbałość o patriotyczne wychowanie młodzieży oraz otaczanie opieką miejsc pamięci narodowej.

\section{„Polsce Wierni” - organ prasowy ZKRP i BWP}

Miesięcznik „Polsce Wierni”, będący organem prasowym ZKRP i BWP, ukazuje się na rynku wydawniczym od 2001 r. i ma nakład 3800 egzemplarzy. Wszystkie artykuły powstają w wyniku związkowej działalności społecznej. Pre-

${ }^{2}$ Związek Kombatantów i Byłych Więźniów Politycznych [dalej: ZKRP i BWP], http://www.kombatant poslki.pl [dostęp: wrzesień-październik 2011]. 
numeraty może dokonać każdy czytelnik za pośrednictwem Zarządów Okręgowych ZKRP i BWP.
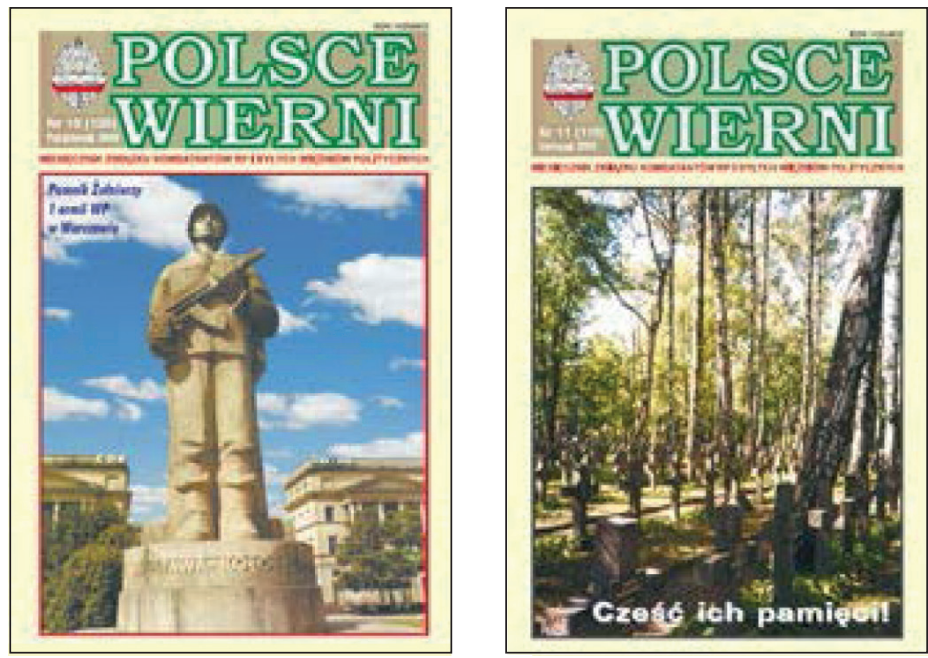

Fot. 1. „Polsce Wierni” - organ prasowy ZKRP i BWP

Źródło: Związek Kombatantów RP i Byłych Więźniów Politycznych, www.kombatantpolski.pl

Gazeta zawiera stałe kolumny, mieszczące wiadomości na temat aktualnej sytuacji i wydarzeń związanych ze Związkiem, przepisy prawne i ich aktualizację odnośnie do kombatantów i podopiecznych, a także wydarzenia kulturalne, oświatowe, w których uczestniczyli działacze Związku. Istnieje również strona prasowa poświęcona nowościom wydawniczym z zakresu historii, wspomnień wojennych oraz książek o tematyce społeczno-politycznej. W czasopiśmie można przeczytać artykuły pisane przez członków ZKRP i BWP oraz osoby przytaczające relacje i wspomnienia swoich bliskich, którzy przeżyli lata wojny i okupacji. W niektórych numerach pisma, choć bardzo ogólnie, udzielano wskazówek z zakresu zdrowia, głównie farmakologii. Do grona stałych współpracowników periodyku należą m.in. gen. bryg. dr Rudolf Dzipanov, prof. Kazimierz Kąkol oraz prof. Tadeusz Rawski.

\section{Kombatanci na spotkaniach z młodzieżą}

Przedstawiony przeze mnie materiał dotyczy współpracy i zaangażowania kombatantów na rzecz edukacji młodego pokolenia. Działalność osób starszych w placówkach oświatowych została udokumentowana na terenie całego kraju. Podczas spotkań kombatanci dzielili się swoimi wspomnieniami z lat wojny i okupacji. Starali się jednocześnie utrwalać pamięć o kolegach, którzy odeszli oraz 
historii związanej z miejscem zamieszkania. Z relacji ze spotkań z młodzieżą wynika, że biorą w nich udział przedstawiciele władz oświatowych oraz władz miast i wsi w wybranych częściach kraju.

W Pszowie Zarząd Koła Miejskiego zorganizował spotkanie, w którym uczestniczyli dyrekcja i nauczyciele historii ze szkoły podstawowej i gimnazjum. Wśród gości obecny był kierownik Referatu Promocji, Oświaty, Kultury i Sportu Urzędu Miasta i dyrektor Zespołu Obsługi Placówek Oświatowych. Dominowały tematy związane z historią Wojska Polskiego i spotkaniami z kombatantami. Razem z młodzieżą dyskutowano o udziale Polaków w bitwie pod Lenino, wyzwalaniu terenów Polski spod okupacji niemieckiej, a także walkach polskich żołnierzy w bitwie o Berlin. Wspominano kapelana Pierwszej Dywizji im. T. Kościuszki, syna ziemi wodzisławskiej, ks. Wilhelma Franciszka Kubsza, zaprezentowano relacje kombatantów dotyczące wyzwolenia Śląska oraz przypomniano sylwetkę gen. Władysława Sikorskiego w 60 . rocznicę śmierci. W prasie na temat spotkania można było przeczytać: ,jednocześnie przy omawianiu poszczególnych tematów, zwraca się uwagę na ich obiektywne naświetlenie i występujące «białe plamy» w historii. Chodzi o to, aby młodzież prawidłowo rozumiała wydarzenia historyczne i ich znaczenie dla niepodległości państwa polskiego"3. W jednym z artykułów napisano, że z okazji 58. rocznicy wyzwolenia stolicy Wielkopolski, w Pecnej koło Poznania dyrekcja Szkoły Podstawowej i Samorządowego Gimnazjum oraz Okręgowa Komisja Społecznej Pracy Organicznej ZO ZKRP i BWP wzięła udział w bloku wychowania patriotycznego. Gości powitała uczennica II klasy gimnazjum Magdalena Żabińska następującymi słowami: „Nasze spotkanie pokoleniowe to czas serdecznej pamięci o tych, co dzisiaj żyją i tych, co oddali swoje życie dla Ojczyzny. Nasze spotkanie pokoleniowe to czas wspomnień o walnym udziale mieszkańców w walkach o wyzwolenie miasta Poznania [...], którzy dzielnie walczyli z żywiołem ratując dobra narodowe". Poza tym dzieci zaprezentowały spektakl, w którym recytowano wiersze i odśpiewano pieśni patriotyczne. Jego uczestnicy byli przygotowani przez nauczycielki, panie mgr L. Szyrę i M. Sroczyńską. Głos zabrali przedstawiciele kombatantów, płk. mgr Stefan Wawrzynowicz, płk. Ryszard Kozubek i płk. Józef Stawicki, którzy podziękowali za organizację uroczystości i liczny w niej udział.

W innym numerze umieszczono informację na temat Zespołu Szkół Elektrycznych nr 2, kierowanego przez dyrektora pan Ryszarda Lisiaka i udziału młodzieży (wspieranej przez Komisję Społecznej Pracy Organicznej Zarządu Okręgowego ZKRP i BWP w Poznaniu) w wycieczce na Cmentarz Wojenny 2 AWP w Zgorzelcu. Wsparcia finansowego całemu przedsięwzięciu udzielił marszałek województwa wielkopolskiego, pan Stefan Misiak. Młodzież wysłuchała wiadomości o postawie i męstwie polskich żołnierzy w bojach i o działalności polskich oddziałów w obronie ludności cywilnej przed ukraińskimi nacjonalistami z UPA oraz akcjach zbrojnych największego ugrupowania partyzanckiego „Bomba” lub „Wujek” pod dowództwem kpt. Władysław Kochańskiego działającego na Zasłuczu. W trakcie uroczystości jeden z uczniów tak podsumował udział w wycieczce: „Dla nas [...] wizyta na Cmen-

${ }^{3}$ S. K r a w c z y k, Patriotyczne wychowanie młodzieży, „Polsce Wierni” [dalej: PW] 2003, nr 6, s. 22.

${ }^{4}$ S. Wawrzy nowicz, Nie rzucim ziemi skąd nasz ród, tamże. 
tarzu Wojennym 2 AWP to wydarzenie szczególne, pobyt w Miejscu Pamięci Narodowej, gdzie razem spoczywa tak liczna grupa patriotów, wzbudza wiele refleksji. W wielkiej zadumie odczytywaliśmy nazwiska poległych żołnierzy"5.

W periodyku czytamy, że 1 września 1954 r. rozpoczęła pracę Szkoła Podstawowa we wsi Rzechta (gm. Sieradz). Pani Romana Klimas, pełniąca obecnie funkcję dyrektora placówki, wystąpiła z inicjatywą nadania szkole (w 50. rocznicę jej powstania) imienia Bohaterów Walk nad Wartą we wrześniu 1939 r. Kombatanci z Sieradza, współpracujący z placówką, wzięli udział w spotkaniu. Reprezentowali ich: prezes Zarządu Miejskiego płk. Tadeusz Trzciński, por. Józef Umiński oraz por. Zbigniew Lewandowicz. Podczas uroczystości zostało powołane Szkolne Koło Kombatantów, do którego zostało zapisanych 30 uczniów. Funkcję przewodniczącej powierzono uczennicy Martynie Bogusławskiej, a rolę opiekuna - pani mgr Beacie Skibińskiej, nauczycielce historii ${ }^{6}$.

Numer czasopisma z 2005 r. zawierał informację, że w Międzyrzeczu z okazji Święta Niepodległości członkowie ZKRP i BWP odbyli spotkania z młodzieżą, w których uczestniczyli por. Antoni Kowalewski, por. Czesław Szagdaj oraz emerytowany nauczyciel Kazimierz Kulas. Wspominano lata wojenne, sytuację na ziemiach polskich w minionym okresie dziejów, działalność organizacji niepodległościowych oraz walki polskich formacji. Szkoły otrzymały Krzyże Katyńskie z krucyfiksem, będące dziełem por. Antoniego Kowalewskiego ${ }^{7}$.

O popularyzację historii Polski i krzewienie patriotyzmu dbało również grono pedagogiczne z Zespołu Szkół Elektryczno-Mechanicznych w Legnicy. Pan Ryszard Grajek, z wykształcenia historyk, nauczyciel dyplomowany, za zgodą dyrektora szkoły, pani mgr Bogusławy Lewandowskiej „zorganizował w placówce muzeum. Zostały w nim zaprezentowane zbiory numizmatyczne, mundury, ordery oraz odznaczenia państwowe. Działania te miały na celu zainteresowanie młodzieży historią i dziejami oręża polskiego. Szkolne zbiory oglądali kombatanci, którzy na co dzień współpracują z placówką. W ich gronie znaleźli się m.in.: por. mgr Władysław Zdzymira, por. Józef Pałys, ppor. Stanisław Dyrkacz oraz ppor. mgr Paweł Albański"8.

„Ojczyzna to nasza ziemia, język, obyczaje, kultura. To nasza serdeczna pamięć o czynach poprzednich pokoleń Polaków i szacunek dla ich dokonań”. Tymi słowami, jak czytamy w jednym z artykułów, powitała gości pani dyrektor Miejskiej Biblioteki Publicznej, Marianna Konieczna-Marjan. Uroczystość miała miejsce w Pieszycach (Dolny Śląsk) z okazji Święta Niepodległości. Odsłonięto wówczas tablicę pamiątkową w Kościele pod wezwaniem św. Antoniego, którą poświęcono „wiecznej pamięci weteranów II wojny światowej w obronie Ojczyzny”. Tablicę ufundowało Koło Miejskie ZKRP i BWP w Pieszycach wraz z mieszkańcami gminy. W uroczystości wzięli udział burmistrz Pieszyc, Mieczysław Obal, ks. Edward Dzik, który ją poświęcił oraz przewodniczący Rady Miejskiej, Tadeusz Urban.

\footnotetext{
5 Pouczająca wycieczka historyczna, PW 2005, nr 7, s. 23.

6 R. KI i m a s, Najciekawsza lekcja historii, PW 2004, nr 4, s. 25.

7 K. Ku la s, Wzruszające spotkania, PW 2005, nr 1, s. 20.

8 Krzewią ducha patriotyzmu, PW 2004, nr 7, s. 6.

${ }^{9}$ Kpt. J. Wi in i r s ki, Tablica pamięci, PW 2005, nr 3, s. 20.
} 
Kolejna uroczystość z udziałem kombatantów miała miejsce również na Dolnym Śląsku, we Wrocławiu. Zarząd Koła nr 53 i Szkoła Podstawowa nr 76 przeprowadzili „lekcje żywej historii”. Program obejmował przekazanie uczniom wiedzy na temat rodzajów, form i sposobów walki oddziałów partyzanckich w okresie II wojny światowej na podstawie przeżyć żołnierzy Armii Krajowej i działań bojowych Oddziału „Frycza” Okręgu Wileńskiego. Pani mgr Mirosława Boluk, nauczycielka historii, dokonała podsumowania spotkań z kombatantami, mówiąc: „Najistotniejszym elementem są lekcje historii w klasach IV-VI. Dla dzieci jest to niepowtarzalna okazja spotkania z żołnierzem AK, który potrafi w sposób barwny i ciekawy opowiedzieć o swoich wojennych przeżyciach"10.

O działaniach na Dolnym Śląsku czytamy w numerze periodyku z 9 kwietnia 2006 r. W Kudowie Zdroju w Zespole Szkół Ponadgimnazjalnych miały miejsce uroczystości upamiętniające zwycięstwo nad faszyzmem. Do grona gości honorowych należeli kombatanci. Podobne spotkania były organizowane przez szkołę każdego roku jako dowód pamięci o walce Polaków o wolność i niepodległość narodu oraz trudzie i ofiarności kombatantów - bohaterów tamtych dni. Dyrektor szkoły, pani Łucja Rachuba, podziękowała kombatantom za udział w uroczystości oraz podkreśliła ich wkład w szerzenie patriotyzmu ${ }^{11}$.

Z kolei starostwo powiatowe w Namysłowie na Śląsku Opolskim zorganizowało 21 października 2005 r. spotkanie, w którym uczestniczyło 80 weteranów. Zaproszone osoby odbyły wycieczkę do pobliskiego Brzegu, gdzie podziwiano nowoczesny sprzęt wojskowy, będący własnością Batalionu Ratownictwa Technicznego. Następnie udano się na spacer do zamku piastowskiego, zwanego „śląskim Wawelem”. W spotkaniu brał udział prezes Zarządu Okręgowego ZKRP i BWP płk. Stefan Szelka, który mówił o potrzebie organizowania podobnych spotkań dla kombatantów. Po raz pierwszy w spotkaniu uczestniczyli uczniowie z Liceum Ogólnokształcącego o profilu wojskowym przy Zespole Szkół Rolniczych - Centrum Kształcenia Ustawicznego w Namysłowie ${ }^{12}$.

$\mathrm{Na}$ uwagę zasługuje artykuł poświęcony spotkaniom świąteczno-noworocznym w Domu Kombatanta, którego autor podkreśla, że dają one starszym osobom możliwość podzielenia się z gośćmi własnymi wspomnieniami. Wizyty składają kombatantom również ich koleżanki i koledzy, dla których taka chwila bywa czasami wyjątkowa, jedyna. Piszący tekst sądzi, że należałoby zwrócić się z apelem do młodzieży i nauczycieli, których odwiedziny byłyby pożądane dla obu stron. Uczestnicy takich spotkań mogliby wiele się nauczyć, a zarazem - miło i sympatycznie spędzić czas podczas ważnych dla większości z nas świąt. $\mathrm{Na}$ przykład w Domu Kombatantów w Warszawie zostały zorganizowane świąteczne spotkania: jedno przy ul. Sterniczej, gdzie mieszka 180 osób i drugie przy ul. Dickensa (zamieszkuje tam 80. pensjonariuszy). Kombatanci otrzymali upominki oraz mieli możliwość podzielenia się wspomnieniami i refleksjami nad minionym życiem. Odwiedzili ich koledzy i koleżanki: Sławomira Zarod, dr Wacław Kolbar-

10 Ppor. E. N y c z, Lekcje żywej historii, PW 2006, nr 9, s. 21.

11 S. Krys t k i e w i c z, Za ofiarny trud i poświęcenie, PW 2005, nr 7, s. 21.

12 E. B. P a wło w s k a, Powiatowe spotkanie z kombatantami w Namysłowie, PW 2006, nr 1, s. 19. 
czyk, Wiesław Jakubowski i Maria Milbrandt - wiceprezes mazowieckiego Zarządu Wojewódzkiego Związku Kombatantów ${ }^{13}$.

W każdej uroczystości brało udział grono pedagogiczne wraz z wychowankami, którzy uczestniczyli w akademiach, recytując wiersze lub śpiewając pieśni patriotyczne. Podczas spotkań przeprowadzono wywiady, prowadzono dyskusje - młodzi ludzie mogli się dowiedzieć o minionych wydarzeniach z historii Polski i Europy bezpośrednio od ich uczestników. Efektywne okazało się także działanie wychowawcze takich spotkań (szacunek, życzliwość, zrozumienie okazywane drugiej osobie). Opisane działania, których inicjatorami byli nauczyciele, kombatanci lub instytucje publiczne, przyczyniły się do rozwijania postaw altruistycznych. Ich zachowanie pozostaje w związku z takimi wartościami, jak: sumienność, uczciwość, pracowitość czy tolerancja ${ }^{14}$.

\section{Współpraca kombatantów z kolegami i koleżankami z zagranicy}

Wzajemna współpraca między kombatantami obejmuje Holandię, Francję, Rosję, Białoruś czy nawet Kanadę. W okresie podlegającym analizie większość materiałów dotyczyła opisu kontaktów i spotkań z terenów wojennych dawnego ZSRR. Wspólną cechą wszystkich uroczystości, które miały miejsce była chęć podtrzymania przyjaźni, dzielenia się wspomnieniami z młodzieżą, szanowanie pamięci tych, co odeszli oraz wydarzeń historycznych z poprzednich lat.

Jako przykład może posłużyć koło terenowe w Obornikach Śląskich, które przyłączyło się do akcji wypoczynkowej dla dzieci i młodzieży z byłych ziem polskich na Wschodzie. Członkowie koła udzielili pomocy finansowej organizatorom i zaprosili osoby przybywające z obszarów wschodnich do swoich domostw. W Obornikach Śląskich gościły dzieci z Litwy, Białorusi i Wołynia. Do współpracy z kombatantami włączyło się Towarzystwo Przyjaciół Grodna i Wilna, a także Towarzystwo Przyjaciół Dzieci. Pan Henryk Sielecki, prezes Koła, otrzymał odznakę „Przyjaciela Dzieci” za prowadzoną działalność15.

W Bielsku Białej w Zespole Szkół Budowlanych im. gen. S. Maczka miało miejsce spotkanie kombatantów z Katowic, Krakowa i Podbeskidzia. Gośćmi honorowymi byli: ambasador Holandii Jan Edward Craan i attaché wojskowy, morski i lotniczy płk. Marinus Kamphuis. Uczestniczyli w nim również przedstawiciele władz, pedagodzy i uczniowie. Kombatanci: Bernard Ditrich, Walenty Janik, Hubert Mojnusz i Józef Zwierzyński zostali udekorowani medalami „Thank You Liberators" 16 .

${ }^{13}$ Świąteczne spotkania w Domach Kombatantów, PW 2009, nr 3, s. 19.

${ }^{14}$ D. U l e w i c z-A d a m c z y k, Kształtowanie postaw altruistycznych wśród młodzieży, [w:] Dylematy współczesnego wychowania i kształcenia, red. A. Augustyn, A. Bodanko, N. Niestolik, Łódź 2011, s. 264.

${ }^{15}$ R. C h waliń s ki, Kombatanci dzieciom Kresów, PW 2003, nr 10, s. 20.

${ }^{16}$ M. Ko pie c, Dziękujemy Wam Weterani, tamże, nr 11, s. 16. 
Z czasopisma „Polsce Wierni” dowiadujemy się na temat współpracy kombatantów polskich i rosyjskich, że Ogólnorosyjska Społeczna Organizacja Weteranów Wojny i Służby Wojskowej z inicjatywy Studia Filmowego "Czyste Stawy” w Moskwie zwróciła się do prezesa Zarządu Głównego ZKRP i BWP gen. Wacława Szklarskiego o okazanie pomocy ekipie operatorów filmowych w realizacji 24-odcinkowego filmu dokumentalnego Święta Wojna. Ideą tego zamierzenia było pokazanie wojny oczami dzieci z czasów Wielkiej Wojny Ojczyźnianej. Serial, częściowo już zrealizowany, obejmował treścią przedstawicieli ruchu oporu m.in.: Austrii, Słowacji, Czech i Niemiec. Rosyjscy filmowcy przebywali w Polsce w dniach 17-21 listopada 2003 r., odwiedzając Oświęcim, Kraków i Warszawę. Spotkali się oni z gen. dyw. Wacławem Szklarskim. W skład delegacji wchodzili m.in.: Tamara Jewgieniewna Pimenowa - producent filmu oraz Edward Redżepowicz - reżyser, scenarzysta i przewodniczący ${ }^{17}$.

Inny artykuł zawierał informację, że w 60. rocznicę wyzwolenia Olsztyna przez oddziały Armii Radzieckiej (22 stycznia 1945 r.) przyjechali z wizytą weterani Kaliningradu, chcący się spotkać z kombatantami Warmii i Mazur. W delegacji rosyjskiej byli: Michaił Nikołajeiwcz Olgin, który wspominał swój bojowy szlak przez Warszawę, Bydgoszcz, Piłę, Kostrzyń, aż do Berlina, Eugeniusz Pacewicz z 1. Dywizji piechoty im. T. Kościuszki oraz Wacław Tomczyk - żołnierz Batalionów Chłopskich. Tematem wiodącym rozmów była wojna i frontowe przeżycia. Złożono wieńce na grobach radzieckich, polskich i francuskich żołnierzy na cmentarzu wojskowym przy ul. Szarych Szeregów. Goście zwiedzili Stare Miasto, miasteczko akademickie w Kortowie oraz obejrzeli kronikę filmową, przedstawiającą walki w Prusach Wschodnich w $1945 \mathrm{r}^{18}$

Kolejne uroczystości z udziałem gości z Rosji miały miejsce w Poznaniu w rocznicę zwycięstwa, którą obchodzono w Cytadeli Poznańskiej. Zgromadzili się tam przedstawiciele władz administracyjnych i samorządowych województwa oraz delegacje jednostek wojskowych, Policji, Straży Pożarnej, instytucji i organizacji kombatanckich, posterunków honorowych Wojska Polskiego, a także Orkiestra Reprezentacyjna Sił Powietrznych. Do uroczystości włączyła się również delegacja Rosyjskiego Komitetu Weteranów Wojny, Pracy, Sił Zbrojnych i Organów Ochrony Prawa z konsulem generalnym Federacji Rosyjskiej w Poznaniu - Władimirem Kuzniecowem i konsulem Siergiejem Siemionowem. Podczas spotkania jego uczestnicy wspominali frontowe przeżycia, koleje losu, walki i pobyt na terenie Polski, wymienili się informacjami o strukturze i działalności związków kombatanckich, zwiedzili Cytadelę Poznańską, złożyli kwiaty pod obeliskiem Armii Radzieckiej oraz na kwaterze Wspólnoty Brytyjskiej ${ }^{19}$.

We wrześniu 1956 r. miało miejsce powołanie do życia Ogólnoradzieckiego Stowarzyszenia Weteranów Wojny, które po zmianach ustrojowych w tym kraju zostało przekształcone w Ogólnorosyjskie Stowarzyszenie Weteranów Wojny i Służby Wojskowej. Z okazji 50-lecia wymienionej organizacji społecznej w Moskwie odbyły się uroczyste obchody rocznicowe (29-30 września 2006 r.), na które

17 Druga wojna światowa w oczach dzieci, PW 2004, nr 1, s. 20.

18 S. W i e I gor z, Wizyta rosyjskich weteranów z Kaliningradu, PW 2005, nr 3, s. 14.

19 J. R a dło w s k i, Wspólne z rosyjskimi weteranami, PW 2006, nr 8, s. 20. 
została zaproszona strona polska. W uroczystościach wzięli udział płk dr Stanisław Całka, przedstawiciel Zarządu Głównego ZKRP i BWP oraz prezes ZG ZKRP i BWP gen. dyw. Wacław Szklarski. Obchodom przewodniczył marszałek lotnictwa Aleksander Nikołajewicz Jefimow, prezes Ogólnorosyjskiego Komitetu Weteranów Wojny i Służby Wojskowej wraz ze swoim zastępcą, gen. płk A. A. Bogdanowem. Podczas spotkania można było poznać bogate zbiory Muzeum Armii Rosyjskiej i Muzeum Wielkiej Wojny Ojczyźnianej. Podziw wzbudziły panoramy, m.in. bitwy kurskiej, obrony Moskwy i blokady Leningradu. Odbył się uroczysty koncert w Kościele Chrystusa Zbawiciela, w którym uczestniczyło ponad 1000 weteranów rosyjskich i zagranicznych ${ }^{20}$.

Polscy kombatanci zostali odznaczeni medalami „60 lat zwycięstwa w Wielkiej Wojnie Ojczyźnianej 1941-1945”, przyznanymi przez ambasadora nadzwyczajnego i pełnomocnego Federacji Rosyjskiej w Polsce Nikołaja Afanasiewskiego, który powiedział do kombatantów polskich i rosyjskich, że ich „wkład w zwycięstwo nad hitlerowskim faszyzmem nigdy nie zostanie zapomniany". W uroczystości, oprócz gen. W. Szklarskiego, uczestniczyli konsulowie rosyjscy - Artur Kuzniecow i Dymitr Niestierow. Medale wręczył attaché wojskowy, morski i lotniczy ambasady rosyjskiej w Polsce, kontradmirał Siergiej Provkin ${ }^{21}$.

14 kwietnia 2006 r. w Krakowie, w siedzibie Zarządu Okręgowego ZKRP i BWP, radca ambasady Republiki Białorusi Gennady Kotowich i attaché obrony, wojskowy i lotniczy ppłk. Siergiej N. Majko wręczyli medale kombatantom polskim, którzy walczyli na ziemi białoruskiej i w bitwie pod Lenino. Odznaczenia zostały wręczone w rocznicę wyzwolenia Białorusi spod okupacji niemieckiej. Stronę polską reprezentowali mjr. w st. spoczynku Józef Kopczyński (prezes Zarządu Okręgu) i kpt. w st. spoczynku mgr Zenon Pikulski (sekretarz). Podczas spotkania dzielili się wspomnieniami z czasów walk wyzwoleńczych i zesłania w głąb ZSRR ${ }^{22}$.

Oprócz współpracy kombatantów polskich i rosyjskich istnieje także więź z ich odpowiednikami w krajach europejskich, np. we Francji. W 60. rocznice zakończenia okupacji niemieckiej Instytut Ambasady Francuskiej w Warszawie zorganizował konferencję (12 listopada 2004 r.) pt. Udział Polaków w wyzwoleniu Francji podczas I/ wojny światowej. Stronę francuską reprezentowali: attaché obrony płk. Jean Sebastian Tavernier, jego zastępca płk. Étienne Champeaux, sekretarz generalny instytutu - Olivier Chaudeon oraz oficerowie Służby Historycznej Wojsk Lądowych - płk Frédéric Guelton, płk Rémy Porte i uczniowie szkoły przy ambasadzie Republiki Francuskiej. Wśród Polaków byli przedstawiciele stowarzyszeń kombatanckich: prezes Zarządu Głównego ZKRP i BWP gen. dyw. Wacław Szklarski, płk Roman Orłowski - Związek Żołnierzy Ludowego Wojska Polskiego, płk Ryszard Białecki - Instytut Naukowy im. gen. E. Rozłubirskiego, a także młodzież akademicka. Uroczystość uświetnił występ Grażyny Skowron-Matkowskiej, która wykonała utwory z repertuaru Edith Piaf przy akompaniamencie Janusza Tylmana. Dyskusje dotyczyły powstania wojska polskiego we Francji,

\footnotetext{
20 Pół wieku Stowarzyszenia Rosyjskich Weteranów, tamże, nr 11, s. 17.

${ }^{21}$ Rosyjskie medale dla polskich kombatantów, PW 2005, nr 7, s. 21.

${ }^{22}$ Białoruskie medale dla weteranów, PW 2006, nr 7, s. 23.
} 
a także udziału Polaków we francuskim ruchu oporu (latem 1944 r. działało w nim 35 tys. naszych rodaków) ${ }^{23}$.

Kolejny artykuł zawierał informację o tym, że 9 kwietnia 2006 r. miało miejsce spotkanie w Pomorskim Muzeum Wojskowym w Bydgoszczy, na którym zgromadziła się młodzież francuska i polscy kombatanci. Młodzi ludzie (20 osób) przybyli z Tuluzy, z Liceum Zawodowego, a ich przyjazd był wynikiem współpracy z Bydgoskim Zespołem Szkół Ekonomiczno-Administracyjnych. W gronie nauczycieli znalazły się dwie przedstawicielki dyrekcji francuskiej szkoły. Pani mgr Aldona Nowakowska pełniła funkcję tłumaczki. Kombatantów reprezentowali: płk. Stanisław Kwaśnicki - uczestnik walk w 1939 r. (Armia Łódź), Zbigniew Podgórski (Pomorska Dywizja Piechoty im. Jana Kilińskiego) i por. Kazimierz Więckowski (Polskie Siły Zbrojne, od 1940 r. walczył we Francji, a następnie w Wielkiej Brytanii). Młodzież była zainteresowana więzami polsko-francuskimi z okresu Księstwa Warszawskiego, dziejami Polskich Sił Zbrojnych podczas II wojny światowej we Francji, Wielkiej Brytanii, we Włoszech, walkami armii polskiej na Wschodzie oraz historią przyjaźni polsko-francuskiej ${ }^{24}$.

Wśród artykułów zamieszczanych w periodyku „Polsce Wierni”, mających wspomnieniowy charakter, znajdują się również teksty o tematyce społeczno-kulturalnej. Jeden z nich został poświęcony zorganizowanym w Polskim Klubie Stowarzyszenia Polsko-Kanadyjskiego w St. Catharines wyborom „Miss Polonii”. Uroczystość odbyła się po raz 60., towarzyszył jej bankiet, który zgromadził 50 „królowych piękności” w przedziale wiekowym 22-80 lat. Panie prezentowały się w strojach wieczorowych z historycznymi szarfami, wzbudzały aplauz wśród gości. Zwyciężyła pani Maria Jakubiak.

Komitetowi przewodniczyła Jadwiga Miarecka. Przemówienie okolicznościowe wygłosił prezes Stowarzyszenia Walter Grobelny, a modlitwę w intencji zebranych odmówił ks. Ryszard Kosian, OMJ. Uroczystość wykraczała poza ramy tradycyjnych wyborów miss piękności, przybliżała historię kanadyjskiej Polonii, łączyła środowiska i pokolenia ${ }^{25}$.

Możliwość współpracy kombatantów z różnych krajów przyczynia się m.in. do wymiany kulturowej i społecznej. Oświata dorosłych może być jedną z form przezwyciężania trudności, wynikających z tempa współczesnych zmian ekonomiczno-społecznych, które mają swój oddźwięk w postawach, przekonaniach, poglądach społeczeństwa, w tym również młodzieży ${ }^{26}$.

Działania edukacyjne pokazują, o jakie wartości należy zabiegać i które powinny być kultywowane. Młodych ludzi cechuje raczej zainteresowanie rzeczami materialnymi kosztem wartości duchowych. Jak pisał M. Marody, mamy do czynienia ze zjawiskiem „«spieniężenia świadomości społecznej», a więc wypierania z niej wartości ponadegzystencjalnych przez wartości materialne, ściśle związane z bytem"27.

${ }^{23}$ Płk. I. Koli ń s k i, Pogłębienie więzi polsko-francuskich, PW 2005, nr 1, s. 16.

24 B. J a godziń s k i, Niecodzienne spotkania, PW 2006, nr 6, s. 21.

25 S. M i e r z w a, Kanadyjscy kombatanci wybierają „miss”, PW 2008, nr 3, s. 24.

26 J. S e m k ó w, W poszukiwaniu nowych wymiarów edukacji dorosłych, [w:] Edukacja dorosłych w sytuacji przemian na tle porównawczym, red. A. Trzuskowski, Łódź 1993, s. 162.

27 M. Marody, Mieć, aby być, [w:] Społeczeństwo polskie u progu przemian, red. J. Mucha, G. Skąpska, Wrocław-Warszawa 1991, s. 29-31. 


\section{Podsumowanie}

Aktywność osób dorosłych prowadzi do rozwoju form oświaty pozaszkolnej, które są związane z propagowaniem kultury. Samokształcenie, kształcenie i wymiana doświadczeń oraz wiedzy między pokoleniami stanowią elementy kształcenia ustawicznego, są także sposobem zwiększania udziału osób dorosłych w wielu dziedzinach aktywności edukacyjnej ${ }^{28}$. Działania szkól, instytucji administracji państwowych i samorządowych, organizacji pracujących na rzecz szeroko pojętej oświaty przyczyniają się do oddziaływania i kształtowania właściwych wzorców w młodym pokoleniu. Udział nauczycieli w uroczystościach poświęconych obchodom świąt narodowych oraz pamięci ważnych wydarzeń historycznych jest bardzo istotny, gdyż pedagog bez sięgania po wartości nie będzie w stanie zbudować autentycznego autorytetu wśród wychowanków ${ }^{29}$. Świat wartości nabiera znaczenia w okresie, kiedy maleje wpływ rodziny, szkoły oraz instytucji wychowawczych ${ }^{30}$. Zaangażowanie kombatantów w naukę i wychowanie młodzieży jest korzystne dla obu stron. Potrzeba wychowania ku wartościom wiąże się z koniecznością niesienia pomocy uczniom w procesie odkrywania i respektowania poznawanych wartości ${ }^{31}$.

\section{s. $175-178$.}

${ }^{28}$ J. P ółturzy cki, Przemiany i perspektywy edukacji dorosłych, [w:] Edukacja dorosłych...,

${ }^{29}$ J. Zi im n y, Autorytet nauczyciela XXI w., [w:] Nauczyciel wobec szans i zagrożeń edukacyjnych XXI w., t. 1: Teoretyczne konteksty szans i zagrożeń edukacyjnych XXI w., red. H. Gajdamowicz, Kraków 2009, s. 143.

${ }_{30} \mathrm{~T}$. W il k, Edukacja, wartości i style życia reprezentowane przez współczesną młodzież w Polsce w odmiennych regionach gospodarczych, Kraków 2003, s. 33.

${ }^{31}$ M. D rze wi e cki, Wychowanie ku wartościom, Warszawa 1998, s. 43. 